\title{
Strategi Adaptasi Pasar Tradisional Dalam Menghadapi Ancaman Ekonomi Masyarakat Ekonomi Asean di Indonesia
}

\section{the Strategies of Traditional Market Adaptation in Facing the Economic Threats of the Asean Economic Market in Indonesia}

\author{
Ambok Pangiuk \\ Fakultas Ekonomi dan Bisnis Islam, UIN Sulthan Thaha Saifuddin Jambi \\ Jl. Arif Rahman Hakim No.111, Simpang IV Sipin, Kec. Telanaipura, Kota Jambi, \\ Jambi 36361 \\ ambok@uinjambi.ac.id
}

\begin{abstract}
Abstrak: Pasar Ekonomi ASEAN (Asean Economic Market) adalah bentuk integrasi ekonomi regional pada tahun 2020. Dengan pencapaian ini, ASEAN akan menjadi pasar tunggal dan produksi berdasarkan aliran barang, jasa, investasi, dan tenaga kerja terampil. Aliran komoditas dan faktor-faktor produksi diperkirakan akan meningkat di bidang pertumbuhan ekonomi dan pembangunan ekonomi yang adil, dan untuk mengurangi tingkat kemiskinan dan perbedaan sosial-ekonomi di kawasan ASEAN. Oleh karena itu, diperlukan strategi adaptasi baru dari kebijakan ekonomi yang didasarkan pada kemampuan mengenali potensi Indonesia. Kemampuan sinergi pemerintah dan pasar diharapkan dapat memperkuat daya saing ekonomi nasional, yang menurut perjanjian pada 2015 akan menghadapi tantangan penyatuan pasar ekonomi ASEAN. Dengan menggunakan metode kualitatif untuk meneliti Strategi Adaptasi Pasar Tradisional dan Pemerintah Kota dalam Anggar Masyarakat Ekonomi Asean (EAC).
\end{abstract}

Kata Kunci: strategi adaptasi, pasar tradisional, masyarakat ekonomi asean

Abstract: ASEAN economic market (AEC) is a form of regional economic integration are planned to be implemented in the 2020's. With these achievements, the ASEAN will become a single market and production base which occurs the flow of goods, services, investment and skilled labor are free as well as capital flows more freely. The flow of commodities and factors of production are 
expected to bring ASEAN into a prosperous and competitive region with equitable economic development, and reduced levels of poverty and socio-economic differences in the ASEAN region. Therefore, we need a new adaptation strategy of economic policy based on the ability to recognize the potential of Indonesia traditional markets. Synergy ability of the government and traditional markets are expected to strengthen the competitiveness of the national economy, which according to the agreement in 2015 will face the challenge of unification of the ASEAN economic market. Using qualitative method to research Traditional Market Adaptation Strategies and City Government in Fancing Asean Economic Community (EAC).

Keywords: strategi adaptasi, pasar tradisional, asean economic market

\section{A. Pendahuluan}

Transformasi adalah sebuah proses perubahan secara berangsur-angsur sehingga sampai pada tahap ultimate, perubahan yang dilakukan dengan cara memberi respon terhadap pengaruh unsur eksternal dan internal yang akan mengarahkan perubahan dari bentuk yang sudah dikenal sebelumnya melalui proses menggandakan secara berulang-ulang atau melipatgandakan.

Dalam rangka kearah mempercepat pertumbuhan ekonomi melalui integrasi ekonomi kawasan, maka pada KTT ASEAN ke-9 di Bali pada tahun 2003 dihasilkan Bali Concord II, yang menyepakati pembentukan ASEAN Community untuk mempererat integrasi ASEAN1․ Terdapat tiga komunitas ASEAN Community yang disesuaikan dengan tiga pilar di dalam ASEAN Vision 2020, yaitu bidang keamanan politik (ASEAN Political-Security Community), ekonomi (ASEAN Economic Community), dan sosial budaya (ASEAN SocioCulture Community). Masyarakat Ekonomi Asean (MEA) adalah tujuan akhir integrasi ekonomi seperti yang dicanangkan dalam ASEAN Vision 2020, adalah "To transform ASEAN into a stable, prosperous, and highly competitive region with equitable economic development, and reduced poverty and socioeconomic disparities (ASEAN Vision 2020)".2 


\section{STRATEGI ADAPTASI PASAR TRADISIONAL DALAM MENGHADAPI ANCAMAN EKONOMI MASYARAKAT EKONOMI ASEAN DI INDONESIA}

Dalam membantu tercapainya integrasi ekonomi ASEAN melalui AEC, maka dibuatlah AEC Blueprint yang memuat empat pilar utama yaitu (1) ASEAN sebagai pasar tunggal dan berbasis produksi tunggalyang didukung dengan elemen aliran bebasbarang, jasa, investasi, tenaga kerja terdidik dan aliran modal yang lebih bebas; (2) ASEAN sebagai kawasan dengan daya saing ekonomi tinggi, dengan elemen peraturan kompetisi, perlindungan konsumen, hak atas kekayaan intelektual, pengembangan infrastruktur, perpajakan, dan e-commerce;(3) ASEAN sebagai kawasan dengan pengembangan ekonomi yang merata dengan elemen pengembangan usaha kecil dan menengah, dan prakarsa integrasi ASEAN untuk negara-negara Kamboja, Myanmar, Laos, dan Vietnam; dan (4) ASEAN sebagai kawasan yang terintegrasi secara penuh dengan perekonomian global dengan elemen pendekatan yang koheren dalam hubungan ekonomi di luar kawasan, dan meningkatkan peran serta dalam jejaring produksi global. ${ }^{3}$

Setelah dihasilkan Bali Concord II para pemimpin negara-negara ASEAN bersepakat mencanangkan Masyarakat Ekonomi ASEAN(MEA) yang bermula disetujui oleh Pemerintah Republik Indonesia dalam KTT ASEAN ke-12, di Cebu, Filipina, 13 Januari 2007 yang diimplementasikan mulai tahun 20154, dan akan dibuka menyeluruh pada tahun 2022. Pembentukan komunitas tersebut diharapkan dapat mewujudkan tercapainya suatu kawasan yang berdaya saing tinggi di kancah internasional ${ }^{5}$. Tujuan utama diberlakukannya Masyarakat Ekonomi Asean (MEA) untuk menjadikan ASEAN sebagai pasar tunggal dan basis produksi, yang mana terjadi arus barang, jasa, investasi dan tenaga terampil yang bebas serta aliran modal yang lebih luas 6 . Dalam artian Masyarakat Ekonomi Asean (MEA) merupakan suatu upaya untuk membentuk pasar bebas antara negara-negara Asia Tenggara yang mana bea masuk barang dan jasa akan dihapus. ${ }^{7}$ Ini akan berdampak terhadap arus lalu lintas produk dari negara ASEAN, termasuk dalam hal ini adalah persaingan barang-barang dari ASEAN ke dalam negeri khususnya di pasar tradisional. 
Di Indonesia, keberadaan pasar tradisional bukan semata urusan ekonomi tetapi lebih jauh kepada norma, ranah budaya, sekaligus peradaban yang berlangsung sejak lama di berbagai wilayah Indonesia ${ }^{8}$. Sebagai pusat kegiatan sosial ekonomi kerakyatan, pola hubungan ekonomi yang terjadi di pasar tradisional menghasilkan terjalinnya interaksi sosial yang akrab antara pedagang-pembeli, pedagang-pedagang dan pedagang-pemasok yang merupakan warisan sosial representasi kebutuhan bersosialisasi antarindividu ${ }^{9}$. Fungsi pasar tradisional selanjutnya menjadi pusat pertemuan, pusat pertukaran informasi, aktivitas kesenian rakyat, bahkan menjadi paket wisata yang ditawarkan. Dalam pemikiran tersebut, pasar tradisional merupakan aset ekonomi daerah sekaligus perekat hubungan sosial dalam masyarakat. Dengan demikian, pasar tradisional bukan hanya sekedar ruang, akan tetapi sebagai lembaga sosial yang terbentuk karena proses interaksi sosial dan kebutuhan masyarakatnya ${ }^{10}$. Pasar tradisional mempunyai fungsi dan peran yang tidak hanya sebagai tempat perdagangan tetapi juga sebagai peninggalan kebudayaan yang telah ada sejak zaman dahulu. ${ }^{11}$

Pasar tradisional merupakan pasar yang memiliki keunggulan bersaing alamiah yang tidak dimiliki secara langsung oleh derasnya pasar-pasar modern ${ }^{12}$. Dalam pasar tradisional perputaran ekonomi masyarakat terjadi. Di pasar tradisional uang beredar dibanyak tangan, tertuju dan tersimpan dibanyak saku, rantai perpindahannya lebih panjang sehingga kelipatan perputaran yang panjang itu berdampak pada pergerakan perekonomian bagi kota dan daerah. Sedangkan pasar modern, semua uang yang dibelanjakan tersedot pada hanya segelintir penerima yang disebut dengan kasir dan efeknya bagi perputaran ekonomi lebih pendek, karena itu sesungguhnya tidak terlalu membawa dampak pada perputaran sektor lain diluar dirinya ${ }^{13}$. Berbeda dengan pasar tradisional yang banyak terdapat usaha mikro atau UMKM, dimana usaha mikro ini menjadi pilar utama ekonomi Indonesia dibandingkan dengan skala usaha makro. ${ }^{14}$ 
Selain daripada itu pasar tradisional memiliki sisi kekeluargaan, kegotong-royongan antara penjual dan pembeli yang menjadi salah satu pemandangan yang indah kala berada di pasar dan bahkan ada juga yang namanya langsung dan itu bisa menjadi hubungan baik dan tak dapat dipisahkan bagaikan persaudaraan yang erat sekali. ${ }^{15}$ Tetapi hal demikian akan terlibas apabila pasar tradisional tidak memiliki strategi untuk bersaing dalam Masyarakat Ekonomi Asean (MEA). Hal ini disebabkan menjamurnya pasar-pasar modern di Indonesia yang memungkinkan pasar tradisional semakin berkurang. ${ }^{16}$ Sehingga, produk-produk impor akan membanjiri pasar tradisional dan bersaing dengan produk lokal. ${ }^{17}$

Melihat daya saing Indonesia dalam skala mancanegara, merujuk pada survei Forum Ekonomi Dunia (WEF) tahun 2012, Indonesia menduduki peringkat ke-50 dari 144 negara yang disurvei. Pada tahun 2011 Indonesia mengalami penurunan indeks daya saing global, dari posisi ke-46 menjadi ke-50 pada tahun 2012. Peringkat terbaik Indonesia adalah pada tahun 2010 berada pada urutan ke-44, yang meloncat dari posisi ke-54 dari tahun sebelumnya. Jika diranking pada level ASEAN, Indonesia berada pada peringkat ke-5. Indonesia masih kalah dari Singapura, Malaysia, Brunei Darussalam dan Thailand dan Timor-Leste menempati urutan terakhir ke13618. Wakil Presiden Jusuf Kalla mengakui, dalam menghadapi MEA ini, Indonesia masih memiliki sejumlah kelemahan, antaranya daya saing yang masih rendah, biokrasi yang belum efisien dan mahalnya energy listrik. ${ }^{19}$

Memasuki pasar bebas yang sudah dimulai tahun 2015 lalu, namun, gejala-gejalanya sudah terlihat sejak tahun 2007, salah satunya yaitu, penurunan kuantitas pasar tradisional. Berdasarkan data dari Kementerian Perindusrian (Kemenpeerin) pada tahun 2007 dan Kementrian Perdagangan (Kemendag) pada tahun 2011 jumlah pasar tradisional di Indonesia mengalami penurunan cukup drastis dari tahun 2007-2011. Pada tahun 2007, jumlah pasar tradisional di Indonesia mencapai 13.450. Tapi pada tahun 2011, jumlahnya tinggal 9.950.20 IKAPPI bahwa Pasar tradisional 
berkurang lebih dari tiga ribu selama periode 2007-2011. Pada waktu yang bersamaan, Asosiasi Pengusaha Ritel Indonesia (Aprindo) juga merilis kenaikan jumlah retail modern yang cukup signifikan tahun 2007-2011. Kenaikannya hampir delapan ribu retail modern ${ }^{21}$. Jadi, pasar tradisional mengalami penurunan lebih dari tiga ribu, sedangkan pasar modern mengalami kenaikan sekitar delapan ribu.

Sedangkan pada tahun 2013 data Badan Pusat Statistik (BPS) menunjukan, pasar modern mengalami peningkatan sebesar 31,4\% sedangkan pasar tradisional mengalami penurunan $81 \% .22$

Jumlah Pasar Tradisional berdasarkan data Badan Pusat Statistik

\begin{tabular}{cc}
\hline Tahun & Pasar Tradisional/Unit \\
\hline 2016 & 15.776 \\
2017 & 15.003 \\
2018 & 14.000 \\
\hline
\end{tabular}

Bila di lihat trend di atas perkembangan pasar tradisional dari tahun ke tahun selalu mengalami kemunduran. Kurang lebih ada 1,625 juta pedagang pasar tradisional terpaksa gulung tikar akibat menjamurnya pasar modern, minimarket, dan supermarket. ${ }^{23}$ Menurut Asosiasi Franchise Indonesia, ada sekitar 400 waralaba asing atau franchise dengan 15.000 gerai yang telah dan akan segera beroperasi di Indonesia ${ }^{24}$. Apabila problem itu dibiarkan seiring berjalannya waktu pasar tradisional yang merupakan warisan kebudayaan bangsa ini akan hilang "tertelan zaman". MEA tidak bisa untuk dihindari, dan merupakan suatu keniscayaan. Oleh karena itu perlu peran Pemerintah sangat diperlukan dalam memformulasikan strategi agar pasar tradisional dapat berdaya saing tinggi.

\section{B. Teori dan Strategis Kompetesi Pasar Tradisional dalam Usaha Pertumbuhan Ekonomi}

Landasan utama penelitian ini adalah al-Qur'an dan as-Sunnah. Fakta mengenai pasar dan perniagaan telah disebutkan dalam kitab suci, ${ }^{25}$ dan mekanisme pasar yang telah dijelaskan dalam Hadits Rasulullah saw ${ }^{26}$. 
Ditambah keputusan Presiden Republik Indonesia Nomor 37 Tahun 2014 tentang Komite Nasional Persiapan Pelaksanaan Masyarakat Ekonomi Association of Southeast Asian Nations (ASEAN). ${ }^{27}$ Peraturan Presiden Republik Indonesia Nomor 112 Tahun 2007 tentang penataan dan pembinaan pasar tradisional, pusat perbelanjaan dan toko modern 28 . Peraturan Menteri Perdagangan No.53/M-DAG/PER/12/2008 menjelaskan tentang pasar tradisional. ${ }^{29}$ Indikator Porter menawarkan diamond model sebagai piranti analisis sekaligus kerangka dalam membangun konsep untuk memperkuat daya saing. Indikatornya adalah empat faktor yang menentukan/National Competitive Advantage (NCA). Empat atribut ini adalah factor conditions, demand conditions, related and suppurting industries, firm strategy, strucure and rivalry. ${ }^{30}$

Konsep daya saing menurut Michael Porter adalah suatu negara memperoleh keunggulan daya saing jika perusahaan/pasar (yang ada di negara tersebut) kompetitif. Daya saing suatu negara ditentukan oleh kemampuan industri/pasar melakukan inovasi dan meningkatkan kemampuannya. Porter menawarkan diamond model sebagai piranti analisis sekaligus kerangka dalam membangun konsep untuk memperkuat daya saing. Dalam perjalanan waktu, diamond model disempurnakan oleh Vietor $\mathrm{H}$. K Richard. (2007) sebagaimana dikutip dari Maswig (2008) yang mengembangkan kerangka pemikiran baru dalam upaya membangun daya saing negara ${ }^{31}$. Berbeda dengan Porter yang melihat perusahaan/pasar sebagai sumber utama daya saing negara, Vietor melihatnya dari perspektif peran pemerintah. Pandangan Vietor sangat beralasan yang dilatarbelakangi fakta bahwa pesatnya arus globalisasi, banyak negara yang berjuang untuk memenangi persaingan untuk mendapatkan teknologi, pasar, keterampilan, dan investasi. Menurut Vietor, pemerintah tidak dapat lepas tangan, membiarkan perusahaan/pasar berjuang sendirian. ${ }^{32}$

Dasar dalam UU Nomor 23 Tahun 201433 mengenai pengembangan potensi daerah salah satunya potensi tersebut adalah pasar tradisional, 
menyatakan bahwa efisiensi dan efektivitas penyelenggaraan pemerintahan daerah perlu ditingkatkan dengan lebih memperhatikan aspek-aspek hubungan antara Pemerintah Pusat dengan daerah dan antar daerah, potensi dan keanekaragaman daerah, serta peluang dan tantangan persaingan global dalam kesatuan sistem penyelenggaraan negara. Letak persoalannya untuk kondisi Indonesia adalah penguatan pasar tradisional untuk dapat berdaya saing ekonomi juga dimaksudkan untuk mengantisipasi dan mempersiapkan Indonesia dalam mengarungi era Masyarakat Ekonomi ASEAN (MEA) 2020. Berkompetesi adalah proses hidup (life is competition) ${ }^{34}$, yang bermaksud hidup bukanlah suatu perlombaan dimana kita harus selalu menang dengan cara apapun tetapi hidup adalah bagaimana selalu meningkat dan belajar untuk menjadi pribadi yang lebih baik dalam menghadapi masa depan. ${ }^{35}$

Kompetisi tersebut bukan hanya terjadi di muka bumi bahkan sampai luar angkasa, star war. ${ }^{36}$ Bahkan seluruh benda-benda alam semesta harus berkompetisi, berkembang, meluas ${ }^{37}$ Sesuai dengan amanat Pembukaan UUD 1945, "Kemudian daripada itu untuk membentuk suatu Pemerintah Negara Indonesia yang melindungi segenap bangsa Indonesia dan seluruh tumpah darah Indonesia dan untuk memajukan kesejahteraan umum, mencerdaskan kehidupan bangsa, dan ikut melaksanakan ketertiban dunia yang berdasarkan kemerdekaan, perdamaian abadi dan keadilan sosial"38. Melihat amanat UUD di atas, bangsa Indonesia harus memiliki kesadaran yang tinggi akan pentingnya berkompetisi, dalam artian harus mampu untuk menjadi negara yang mandiri, tidak bergantung kepada bantuan luar negeri (hutang), dan meminta baniuan kepada negara-negara lain.

Apabila seluruh elemen bangsa berupa Sumber Daya Manusia yang lebih dari 200 juta orang agar dikoordinir mengolah Sumber Daya Alam Indonesia berupa materil, dan juga kekayaan negara Indonesia immaterial berupa kebudayaan dan termasuk di dalamnya adalah pasar tradisional yang merupakan salah satu warisan kekayaan Indonesia, dapat dipastikan Indonesia dapat mandiri dan mampu berkompetisi dengan negara-negara 
lain. Peran pasar tradisional sangat besar dalam perekonomian yang lebih menggambarkan denyut nadi perekonomian rakyat Indonesia ${ }^{39}$. Pasar tradisional sebagai pondasi dasar ekonomi kerakyatan, sekaligus sebagai jantungnya ekonomi masyarakat. Kekuatan ekonomi makro bangsa berasal dari kekuatan mikro yaitu dari masyarakat bawah yang didominasi pasar tradisional dan menjadi tulang punggung perekonomian negara ${ }^{40}$.

Kekuatan mikro ini sangat efektif di dalam menghadapi krisis ekonomi global. Ini terbukti ketika terjadi krisis ekonomi tahun 1998, pasar tradisional dapat bertahan menghadapi krisis tersebut karena tidak bersentuhan langsung dengan dolar AS atau mata uang asing lainnya ${ }^{41}$. Dasar dari perekonomian nasional adalah pasar tradisional, dengan lumpuhnya ekonomi makro di beberapa tempat tetapi kegiatan perekonomian rakyat berupa pasar tradisional memberikan kontribusi yang sangat signifikan terhadap pertumbuh makro ekonomi negara. Pertumbuhan ekonomi yang dipegang oleh beberapa pengusaha kelas atas saja merupakan pertumbuhan ekonomi yang imajiner. Tetapi pertumbuhan ekonomi yang melibatkan masyarakat bawah, merupakan pertumbuhan ekonomi yang real (bottom up).

Oleh karenanya, Pemerintah memiliki peranan yang sangat fundamental untuk memajukan pasar tradisional, yang selama ini kurang disadari bahwasannya pasar tradisional jauh memiliki peran lebih mendalam untuk memajukan roda ekonomi negara. Dengan peran Pemerintah di dalam Pasar Tradisional, menjadi sandaran kuat bagi Pasar Tradisional untuk berkompetisi dengan ritel-ritel modern dan juga globalisasi Masyarakat Ekonomi Asean (MEA).

\section{Transformasi dan Sejarah Pasar Tradisional Angso Duo Kota Jambi, Pasar Tradisional 16 Ilir Kota Palembang dan Pasar Tradisional Cipulir Jakarta Selatan}

Dalam berkompetisi memerlukan strategi. Setiap strategi memiliki keunikan. Tidak ada suatu strategi kompetisi khususnya dalam usaha 
ekonomi yang paten dan dapat menjadi rumusan yang unggul dan sesuai dengan semua usaha ekonomi. Karena setiap usaha memiliki kebutuhan, tujuan dan lingkungan yang berdeda. Oleh karenanya setiap usaha memiliki strategi yang berbeda dalam memenuhi keperluan sehari-hari. Perbedaan tersebut dipengaruhi oleh beberapa faktor:

1. Struktur segmentasi pasar. ${ }^{42}$

2. Jenis usaha dan produk. ${ }^{43}$

3. Posisi tempat ${ }^{44}$.

4. Adanya kompetitor utama ${ }^{45}$.

5. Penetapan harga 46

Beberapa fungsi pasar tradisional yang berhasil penulis rangkum di antaranya: 47

1. Sebagai perantara untuk menyampaikan barang dan jasa kepada konsumen.

2. Distribusi hasil produksi barang atau jasa dengan produktifitas.

3. Mengorganisir produksi dengan metode produksi yang lebih efisien.

4. Mengadakan penjatahan setiap barang dan jasa yang tersedia.

5. Penyediaan barang/jasa untuk masa mendatang.

6. Pasar Tradisional peninggalan yang ada sejak zaman dahulu. ${ }^{48}$.

Dalam sejarah peradaban manusia semua tidak lepas dari air ${ }^{49}$. Timbulnya peradaban dikarenakan di sana terdapat sumber air yang melimpah khususnya sungai sebagai wadah munculnya peradaban umat manusia $^{50}$. Sebagai contoh lembah Sungai Nil (Mesir tahun 4000 SM) Afrika, lembah Sungai Eufrat dan Tigris (Mesopotamia-Irak 3000 SM) Asia Barat, lembah Sungai Indus dan Sungai Gangga (India 3000 SM) Asia, lembah Sungai Huang Ho (Kuning) Cina Utara51. Di tempat aliran-aliran sungai itu tumbuh pelabuhan-pelabuhan dagang (pasar-pasar) dimana manusia melakukan transaksi. Begitupun dengan pasar tradisional Angso Duo Kota Jambi, pasar tradisional 16 Ilir Kota Palembang dan pasar tradisional Cipulir Jakarta 
Selatan, yang cikal bakalnya berasal dari peradaban manusia tepian sungai dan pelabuhan.

Dalam mentransformasikan pasar tradisional menjadi pasar modern tanpa menghilangkan ciri khas dari pasar tradisional itu sendiri ${ }^{52}$. Transformasi tersebut haruslah dimulai dari pembangunan infrastruktur untuk membangun keperluan asas manusia/masyarakat yaitu; tersedianya air pdam yang melimpah, energy/listrik yang murah dan fasilitas jalan sebagai urat nadi perekonomian ${ }^{53}$. Dengan pembangunan infrastruktur yang dapat mencukupi keperluan asas manusia, dengan otomatis suatu peradaban akan berkembang pesat. Begitupun dengan pembangunan infrastruktur pasar tradisional, yang sebelumnya terkesan kumuh, kotor, becek, sanitasi air yang tidak lancar dan lain sebagainya, kini imej tersebut akan berganti apabila infrastruktur dibangun dalam memenuhi keperluan asas yang terdapat di pasar tradisional tersebut.

Berdasarkan permasalahan yang sangat mendasar di atas, maka diperlukan adanya pasar tradisional dengan penataan modern khususnya di Pasar Angso Duo, Pasar 16 Ilir Palembang dan Pasar Cipulir Jakarta Selatan, juga seluruh pasar tradisional yang berada di seluruh Negara Kesatuan Republik Indonesia (NKRI) sebagai pasar tradisional yang dapat mengakomodir keamanan, kebersihan, dan kenyamanan dalam bertransaksi, sehingga dapat mewujudkan pasar tradisional yang aman, sehat juga nyaman. Pasar tradisional dengan membawa konsep modern ini juga diharapkan mampu menyediakan fasilitas-fasilitas perdagangan demi kelancaran aktifitas perdagangan di kota-kota tersebut.

Pasar modern harus mampu mengatasi pasar tumpah dengan disediakan tempat luas dibelakang bangunan utama agar tidak mengganggu lalu lintas di Jalan Raya. Kejadian yang terdapat di Pasar Tradisional Angso Duo adalah keadaan pasar dimana puluhan pedagang menggunakan fasilitas jalan umum untuk berjualan, bahkan bukan hanya itu, jalan umum pun yang diberi nama jalan Sulthan Thaha Saifuddin dijadikan tempat berjualan dan tempat parkir. 
Keadaan ini mengakibatkan kemacetan setiap hari. Mungkin pasar tumpah di Pulau Jawa hanya terjadi ketika menjelang perayaan hari raya seperti hari raya Idul Fitri, hari raya Idul Adha, perayaan tahun baru dan lain sebagainya. Tetapi di Pasar Angso Duo setiap hari terjadi pasar tumpah dikarenakan migrasinya para pedagang di dalam pasar ke jalan umum akibat sering terjadi air pasang Sungai Batanghari.

Begitu juga dengan Pasar Tradisional 16 Ilir, pemandangan pasar tumpah ruah dimana pedagang kaki lima memenuhi badan, meskipun telah ditertibkan oleh Polisi Pamong Praja. Pasar tumpah ini banyak mengambil sebagian badan jalan terutama yang berada di depan pasar. Penampakan sama juga ditemukan di Jalan Masjid Lama yang tidak kalah carut marutnya dan menyebabkan lalu lintas terganggu oleh pedangang kali lima yang menjajakan jualannya di sepanjang jalan tersebut.

Berbeda dengan kondisi Pasar Tradisional Cipulir yang terletak di Jalan Raya Cileduk, Kelurahan Cipulir, Kecamatan Kebayoran Lama, Jakarta Selatan. Posisi pasar berada langung di tepi jalan raya, bangunan pasar sudah semi-modern. Pasar tumpah tidak terjadi di sini, tetapi kemacetan kerap kali terjadi disebabkan tempat pemberhentian mobil, barang dan orang atau pun penumpang yang keluar masuk pasar. Selain dari itu, di Pasar Cipulir menjadi kawasan langganan banjir kiriman berasan dari kawasan Puncak Kabupaten Bogor melalui Kali Pesanggrahan. Genangan air mencapai 50 centimeter yang merembes melalui 30 titik rembesan di tepian kali tersebut. Revitalisasi Pasar Tradisional Cipulir menjadi solusi terbaik.

\section{Strategi Pemerintah Kota dan Revitalisasi Pasar Rakyat/Tradisional dalam Menghadapi Masyarakat Ekonomi Asean}

\section{Pasar Tradisional Angso Duo}

Para pedagang di Pasar Tradisional Angso Duo memilik jenjang pendidikan yang beragam. Tingkat pendidikan tersebut yang mendominasi tingkat SMP/sederajat sebanyak 15 orang atau 49,8\%, kemudian 
SD/sederajat sebanyak 13 atau 43,3\%, SMA/sederajat hanya 2 orang atau 6,9\%. Profesi mereka full atau 100\% adalah sebagai pedagang dan bukan pekerja sambilan. Pendapatan sehari-hari lebih mendominasi di atas 500 ribu sampai dengan 1 juta rupiah sejumlah 18 orang, di bawah 500 ribu hanya 11 orang adalah, dan 1 orang dengan jumlah yang lain.

Status kepemilikan toko/tempat usaha adalah kebanyakan dengan sewa sebanyak 24 orang, punya sendiri sebanyak 4 orang dan milik pemerintah sebanyak 2 orang. Para pedagang pun tidak mengetahui jumlah pedangan yang ada di Pasar Angso Duo, semua hanya perkiraan saja dari 200 sampai dengan 1000 orang pedagang. Adapun pengetahuan para pedagang di Pasar Angso Duo tentang persaingan pasar global sebanyak 28 orang tidak mengetahui tentang adanya persaingan pasar global, atau 93,4\% tidak mengetahui. Hanya 2 orang saja yang mengetahui atau 6,6\% saja. Sedangkan secara khusus ditanya tentang Masyarakat Ekonomi Asean (MEA) 29 orang menyatakan tidak mengetahui akan hal tersebut atau 96,7\% pedagang di Pasar Angso Duo tidak mengetahui tentang adanya Masyarakat Ekonomi Asean (MEA), hanya 1 orang saja yang tahu atau 3,3\% yang mengetahui tentang adanya Masyarakat Ekonomi Asean (MEA).

Dari data mengenai pengetahuan pedagang mengenai Masyarakat Ekonomi Asean (MEA) yang hanya 1 orang mengetahui atau 3,3\% dan yang tidak mengetahui sebanyak 29 orang atau sebesar 96,7\%. Ini berbanding lurus dengan pengetahuan pedangang tentang/mengenai Masyarakat Ekonomi Asean (MEA) yang hanya 1 orang mengetahui atau 3,3\% dan yang tidak mengetahui sebanyak 29 orang atau sebesar 96,7\%. Begitupun mengenai pengetahuan para pedagang mengenai kapan diberlakukannya Masyarakat Ekonomi Asean (MEA) hanya 1 orang yang mengetahui atau 3,3\% dan yang tidak mengetahui sebanyak 29 orang atau sebesar 96,7\%. Mengenai tujuan diberlakukannya Masyarakat Ekonomi Asean (MEA) para pedagang pasar 96,7\% atau 29 orang tidak mengetahui dan hanya 1 orang yang mengetahui atau setara dengan 3,3\%. 


\section{STRATEGI ADAPTASI PASAR TRADISIONAL DALAM MENGHADAPI ANCAMAN EKONOMI MASYARAKAT EKONOMI ASEAN DI INDONESIA}

Mengenai efektifitas pemerintah dalam memberikan informasi mengenai persaingan perdagangan global dan Masyarakat Ekonomi Asean (MEA) kepada masyarakat khususnya para pedagang di Pasar Angso Duo, sebanyak 28 orang atau 92,9\% menyatakan pemerintah belum efektif memberitahukan mengenai hal tersebut kepada masyarakat khususnya para pedagang, hanya 2 orang atau 7,1\% yang menyatakan pemerintah pernah memberitahukan akan hal tersebut. Kesiapan para pedagang untuk menghadapi Masyarakat Ekonomi Asean (MEA) hanya 33\% atau 10 orang yang siap untuk menghadapi hal tersebut, dan $67 \%$ atau 20 orang tidak siap untuk bersaing dalam Masyarakat Ekonomi Asean (MEA). Ketidak siapan para pedangang mungkin diakibatkan oleh kurangnya penyuluhan, pelatihan atau pun pembinaan oleh pemerintah kepada para pedagang. Hal ini dinyatakan oleh 22 orang pedagang atau $66 \%$ bahwa pemerintah tidak pernah memberikan pelatihan dan penyuluhan kepada para pedagang mengenai era persaingan Masyarakat Ekonomi Asean (MEA). 8 orang saja atau 37\% yang menyatakan pemerintan sudah pernah memberikan penyuluhan kepada pedagang masyarakat pasar.

Apakah dengan diterapkannya Masyarakat Ekonomi Asean (MEA) akan mempengaruhi roda ekonomi di Pasar Tradisional Angso Duo? Data yang diperoleh untuk menjawab pertanyaan ini dari para pedagang pasar adalah $50 \%$ atau 15 orang pedagang menjawab berpengaruh sedangkan 15 orang yang lain atau 50\% menjawab tidak berpengaruh. Masukan serta harapan para pedagang di Pasar Tradisional Angso Duo kepada Pemerintah Kota Jambi khususnya adalah; Pemerintah agar memperhatikan rakyat dan pedagang kecil, permodalan agar diberikan dengan cara yang mudah. Penstabilan harga harus kerap dilakukan agar ekonomi dapat berjalan baik. Keadilan serta keberpihakan haruslah kepada masyarakat lokal. Penyuluhan dan pelatihan harus selalu dilakukan agar sumber daya manusia (SDM) para pedagang dapat meningkat. 
Kata "tradisional" merupakan icon Pasar Tradisional Angso Duo dan Pasar Tradisional Angso Duo harus dipertahankan. Kata tradisional akan selalu melekat kepada Pasar Angso Duo meskipun pasar ini telah bertrasformasi menjadi pasar semi modern dan modern. Kemodernan ini nampak dengan akan digunakannya digitalisasi di Pasar Tradisional Angso Duo, seperti; parkir yang akan menggunakan palang otomaris bertiket berbayar, pencantuman di layar digital harga-harga kebutuhan pokok seharihari serta fluktuasi harganya setiap hari, pengumuman digital baik visual maupun audio visual, sistem manajerial yang modern, kebersihan, betonisasi pasar agar tidak becek, kumuh dan baru, dan lain sebagainya, serta peluasan pasar yang terus berlanjut untuk dapat menampung ribuan pedagang yang lama dan baru.

Berdasarkan hasil interview mengenai anggaran revitalisasi belum ada, karena Pasar Tradisional Angso Duo dibangun oleh para pengembang yang bekerja sama dengan Pemerintah Propinsi Jambi54. Pembangunan Tradisional Pasar Angso Duo di atas lahan hibah dari Pemerintah Provinsi Jambi. Pembangunan pasar dilakukan secara swadana atau melalui kerjasama dengan swasta. Pembangunan ini dilakukan di atas lahan seluas 8,7 hektar dan dapat menampung kurang lebih 4.897 pedagang. Lahan tersebut terletak bersebelahan di Pasar Angso Duo lama, di tepi Sungai Batanghari, Kecamatan Pasar Jambi, Kota Jambi. Sesuai master plan, Pasar Angso Duo dibangun tiga lantai. Pasar atas 2.433 los, 1.400 kios, 161 lapak serta 580 tempat pedagang kali lima. Serta dibangun 100 unit ruko dan 233 toko di bagian depan pasar.

Mengenai regulasi revitalisasi pasar tradisional semua sudah terkoneksi antara Pemerintah Provinsi Jambi dan Pemerintah Pusat maupun kerjasama dengan pihak swasta. Revitalisasi ini telah dijelaskan dalam Peraturan Menteri Perdagangan Republik Indonesia tentang Pedoman Pembangunan dan Pengelolaan Sarana Perdagangan55. Peraturan Menteri ini bertujuan untuk memberikan pedoman bagi pemerintah pusat, pemerintah daerah, 
badan usaha milik negara, badan usaha milik daerah, koperasi atau swasta dalam melaksanakan pembangunan/revitalisasi dan pengelolaan sarana perdagangan. Dengan akan rampungnya pembangunan di Pasar Tradisional Angso Duo yang baru maka kualitas pelayanan dan tata kelola pasar akan ditingkatkan dibuat maksimal untuk dalam depannya. Kemitraan dan promosi besar-besaran, memperkenalkan Pasar Tradisional Angso Duo akan dilakukan dengan menggunakan e-tecnology contoh yang paling nyata adalah penggunaan Content Management System (CMC) pada e-commerce.

Pemerintah Kota Jambi pun akan memperhatikan dan meningkatkan komoditi unggulan di Kota dan Provinsi Jambi. Pengolahan komoditas unggulan ini berasal dari luar Kota Jambi seperti salah satu daerah di Provinsi Jambi yaitu Kumpeh yang merupakan sebuah Kecamatan di Kabupaten Muaro Jambi memiliki hasil alam berupa dukuh. Dukuh merupakan komoditi unggulan dari daerah ini. Masyarakatnya sebagian besar adalah petani dukuh. Inisiatif serta inovasi dari pemerintah sangat diperlukan untuk merubah/mengolah hasil alam dukuh ini agar menjadi produk unggulan di masyarakat Jambi yang berasal dari Kumpeh. Contoh tempat lain yang memiliki sumber daya alam bagus yaitu daerah Tangkit Baru yang sudah sejak lama dikenal sebagai sentral nanas dari Jambi, terdapat juga tugu nanas di daerah ini. Dari sumber daya alam yang ada sangat kondusif untuk dikembangkan sebagai usaha ekonomi kreatif bagi masyarakat yang dapat menghasilkan produk unggulan berstandar internasional, International Organization for Standardization (ISO). Berstandar Internasional tetapi tetap mempertahankan aspek-aspek tradisionalnya.

Pemerintah pun tidak akan lepas untuk mengembangkan strategi agar pasar tradisional dapat bersaing di era perdagangan global dengan cara meningkatkat kualitas produk lokal untuk dipasarkan di mancanegara, harga yang dapat bersaing, melayani dengan sepenuh hati, ramah/hamble dan lain sebagainya. Dengan diterapkannya Masyarakat Ekonomi Asean Pemerintah 
Kota Jambi menyambut positif dan optimis dapat bersaing dengan produkproduk dari negara lain.

\section{Pasar Tradisional 16 Ilir Palembang}

Setelah penulis melakukkan observasi dan interview terhadap beberapa pedagang di Pasar Tradisional 16 Ilir Palembang didapati bahwa para pedagang memiliki jenjang pendidikan yang bervariasi. Tingkat pendidikan SMA/sederajat sebanyak $43,2 \%$ atau 13 orang, SMP/sederajat 12 orang atau $40 \%$, SD/sederajat 3 orang atau 10\%, tidak sekolah 3,3\% atau 1 orang dan diploma 3,3\% atau 1 orang. Di salah satu blok Pasar Tradisional 16 Ilir pedagang dengan tingkat pendidikan SMA/sederajat adalah yang mendominasi. Dalam status pekerjaan, yang pure sebagai pedagang/wirausaha adalah 18 orang atau 59,9\%, sedangkan sebagai pegawai swasta 11 orang atau 36,6\%, serta pekerjaan lain 1 orang atau 3,3\%. Pendapatan perhari yang di bawah 500 ribu rupaiah adalah 28 orang atau 93\% dan di atas 500 ribu 6,7\%. Status kepemilikan toko mendominasi adalah hak guna pakai 96,9\% dan milik sendiri adalah 3,3\% atau 1 orang. Melihat kepada pengetahuan para pedagang mengenai persaingan pasar global 89,9\% tidak mengetahui atau 27 orang, hanya 9,9\% atau 3 orang saja mengetahui tentang adanya persaingan pasar global. Tetapi pengetahuan pedagang pasar mengenai Masyarakat Ekonomi Asean (MEA) 24 orang mengetahui atau $80 \%$ sedangkan $20 \%$ atau 6 orang tidak mengetahui akan hal tersebut.

Waktu diberlakukannya Masyarakat Ekonomi Asean (MEA) 83,3\% atau 25 orang orang mengetahui, sedangkan pedagang mengetahui tentang kapan berlakunya Masyarakat Ekonomi Asean (MEA) hanya 16,7\% atau 5 orang. Tujuan dari Masyarakat Ekonomi Asean (MEA) yang mengetahui hanya 6,7\% atau 2 orang, sedangkan tidak mengetahui 28 orang 92,3\%. Efektifitas pemerintah dalam mensosialisasikan informasi tentang Masyarakat Ekonomi 
Asean (MEA) hanya 6,7\% atau 2 orang, selebihnya 92,3\% pemerintah belum memberitakan.

Kesiapan para pedagang pasar dalam menghadapi persaingan Masyarakat Ekonomi Asean (MEA) hanya 23,3\% atau 7 orang, sedangkan selebihnya sebesar 76,7\% belum siap dalam menghadapi Masyarakat Ekonomi Asean (MEA). Peran pemerintah berupa pemberian penyuluhan/pelatihan terhadap pedagang pasar sebanyak 53,3\% atau 16 orang belum pernah, sedangkan $46,7 \%$ atau 14 orang menyatakan pemerintah sudah mengadakan pembinaan untuk meningkatkan sumber daya manusia (SDM) menghadapi Masyarakat Ekonomi Asean (MEA). Tanggapan lain dari masyarakat mengenai diterapkannya Masyarakat Ekonomi Asean (MEA) mempengaruhi roda perekonomian pasar tradisional, 29 orang atau 96,6\% menyatakan dapat mempengaruhi roda perekonomian sedangkan $3,4 \%$ atau 1 orang menyatakan tidak.

Antisipasi sekaligus strategi para pedagang dalam menghadapi Masyarakat Ekonomi Asean (MEA) adalah dengan meningkatkan sumber daya manusia (SDM), meningkatkan kualitas produk, bersaing harga di pasar bebas, memperbaiki pelayanan dengan ramah sesuai budaya Indonesia, berusaha menyesuaikan diri/beradaptasi dengan adanya persaingan global, meningkatkan produktivitas secara efektif dan efisien, dan terus meningkatkan kemampuan berbicara, negosiasi serta strategi perdagangan. Masukan dan kritik bagi pemerintah dalam menghadapi Masyarakat Ekonomi Asean (MEA), untuk lebih menggalakan pelatihan, penyuluhan dan pendidikan dalam meningkatkan sumber daya manusia (SDM) agar dapat bersaing dalam Masyarakat Ekonomi Asean (MEA), memberi bantuan modal dan tempat usaha yang permanen, meningkatkan kepercayaan masyarakat terhadap pemerintah, serta kebijakan pemerintah yang berpihak kepada masyarakat lokal dan rakyat kecil. 


\section{Pasar Tradisional Cipulir Jakarta Selatan}

Observasi dan interview dilakukan dengan para pedagang di Pasar Tradisional Cipulir. Dan setelah melakukan peninjauan lapangan didapati bahwasannya jenjang pendidikan para pedagang didominasi oleh lulusan SMA/sederajat sebanyak $46,6 \%$ atu 14 orang, SMP/sederajat $40 \%$ atau setara dengan 12 orang sedangkan yang lulus SD/sederajat 13,4\% atau 4 orang. Status pekerjaan para pedagang $100 \%$ adalah para wirausahawan, meraka sebagai owner dari kios atau tempat mereka berniaga bukan sebagai pegawai, pelajar atau pun hanya sampingan saja. Pendapatan berniaga harihari rata-rata berkisar 500 ribu sekitar $80 \%$ atau 24 orang, berpendapatan rata-rata di atas 500 ribu adalah $16,7 \%$ atau sebanyak 5 orang dan berpendapatan 1 juta perhari sebanyak 3,3\% atau 1 orang.

Status kepemilikan toko atau lahan, sebanyak 15 orang atau 50\%, sedangkan berstatus masih sewa sebanyak 33\% atau 10 orang, masih milik pemerintah sebanyak 17\%, untuk hak guna pakai tidak. Pengetahuan serta wawasan mengenai persaingan global kebanyakan mengetahui tentang hal itu sebanyak 86,6\% atau 26 orang, sedangkan yang tidak mengetahui sebanyak 13,4\% atau 4 orang. Begitu juga tentang Masyarakat Ekonomi Asean (MEA) mayoritas dari pembeli mengetahui akan hal tersebut sebanyak $56,6 \%$ atau 23 orang sedangkan yang tidak mengetahui sebanyak $23,4 \%$ atau 7 orang. Pengetahuan para pedagang mengenai waktu dimulainya Masyarakat Ekonomi Asean (MEA) sebanyak 17 orang atau 56,6\% mengetahui, dan sebanyak 13 orang tidak mengetahui atau 43,4\%. Mengenai tujuan dari Masyarakat Ekonomi Asean (MEA) sebanyak 17 orang atau $56,7 \%$ mengetahi, sedangkan hanya $43,3 \%$ orang atau 13 orang.

Mengenai efektifitas pemerintah dalam menginformasikan tentana Masyarakat Ekonomi Asean (MEA) ke masyarakat pasar sebanyak 70\% masyarakat menyatakan pemerintah sudah efektif di dalam menginformasikan Masyarakat Ekonomi Asean (MEA) ini, 7 orang atau $26,7 \%$ menyatakan belum memberitakan, dan hanya 1 orang yang 
berpendapat lain atau 3,3\%. Kesiapan masyarakat pasar dalam menghadapai Masyarakat Ekonomi Asean (MEA) sebanyak 90\% masyarakat siap dalam menghadapi masuknya Masyarakat Ekonomi Asean (MEA), tidak siap hanya $6,7 \%$ dan lain-lain 3,3\% atau hanya 1 orang. Penyuluhan dan pelatihan mengenai Masyarakat Ekonomi Asean (MEA) kepada masyarakat pasar menyatakan 19 orang atau 63,4\% sudah pernah mengikuti penyuluhan tersebut, 9 orang atau 30\% belum pernah, dan lain-lain hanya 6,6\% atau 2 orang. Berpengaruh tidaknya diberlakukannya Masyarakat Ekonomi Asean (MEA) terhadap roda perekonomian pasar tradisional 23 orang menyatakan berpengaruh atau 76,7\%, 5 orang menyatakan tidak berpengaruh atau 16,7\% dan 2 orang menyatakan lain atau 6,6\%.

Untuk mengantisipasi terhadap datangnya Masyarakat Ekonomi Asean (MEA) para pedagang akan memperbaiki kualitas dagangannya, bekerjasama menggunakan produk lokal, harup mempersiapkan diri dalam meningkatkan SDM maupun produk yang dihasilkan agar dapat bersaing, mengikuti pelatihan-pelatihan dan penyuluhan yang diadakan oleh pemerintah daerah setempat, berusaha untuk dapat cepat beradaptasi dengan baik terhadap perubahan global, memberikan pelayanan terbaik kepada pelanggan dan konsumen, berusaha untuk menjadi pedagang yang cerdas, memperluas kegiatan perekonomian dengan bekerjasama dengan semua pihak, meningkatkan kualitas dalam setiap sektor usaha, harus banyak belajar dalam meningkatkan kualitas SDM, meningkatkan kualitas produk dan jasa dari segi standar SNI, dan memahami keinginan pasar dalam setiap segi apapun.

Strategi para pedagang dalam menghadapi Masyarakat Ekonomi Asean (MEA); Meningkatkan seluruh infrastruktur yang ada atau revitalisasi pasar tradisional, memberikan pelayanan terbaik pembeli, memberi kepercayaan kepada konsumen, sopan dan ramah dengan pelanggan agar tetap berbelanja menjadi pelanggan setia, memperbaiki kwalitas yang ada, memberikan yang terbaik untuk para pelanggan, kualitas dan kuantitas produk untuk terus 
diperbaiki, lebih kreatif dan inovatif lagi dalam mengembangkan produk agar mampu bersaing dalam era global, berani mengambil resiko yang ada, harus mampu bersaing baik dari segi SDM maupun produk dan menjual barang disesuaikan dengan permintaan pasar.

Saran serta masukan bagi pemerintah daerah dalam menghadapi Masyarakat Ekonomi Asean disampaikan oleh para pedagang adalah diharapakan pemerintah agar lebih memperhatikan lagi dan meningkatkan kemampuan para pedagang mikro kecil dan menengah UMKM, diharapkan pemerintah untuk dapat meningkatkan pertumbuhan ekonomi dengan memberikan bantuan usaha kepada para pedagang, hentikan impor agar produk dalam negeri berkembang pesar, kebijakan pemerintah untuk lebih adil lagi berpihak kepada rakyat, memberikan sasaran bantuan yang tepat kepada masyarakat, mensosialisasikan dengan luas program-program pemerintah kepada masyarakat, mewujudkan kesejahteraan ekonomi, mempertahankan tingkat harga yang stabil, memberikan binaan penyuluhan dan pelatihan kepada masyarakat agar SDM dapat meningkat, negara harus kuat untuk mendorong kegiatan usaha yang ada di Indonesia agar siap bersaing.

Di samping itu peran pemerintah selalu memantau kembali patokan harga yang sesuai di masyarakat, pemerintah memiliki konsistensi melindungi pasar domestik dan mencegah masuknya barang impor seludupan, lebih matang lagi dalam menghadapi pasar global yang meliputi setiap sektor usaha, lebih mengembangkan kawasan pasar bebas, lebih teliti lagi dalam mensotir barang agar kwalitas terjamin dengan demikian barang domestik Indonesia mampu bersaing di pasar internasional, pemerintah lebih intens dalam mensosialisasikan Masyarakat Ekonomi Asean (MEA) agar masyarakat dapat lebih siap dalam menghadapi persaingan tersebut.

Dalam kondisi Pasar Tradisional Angso Duo tidak kalah semrautnya diakibatkan para Pengusaha Kecil Mandiri (PKM) yang berjualan lapak di badan jalan sehingga tidak heran apabila kemacetan sering terjadi. 
Pemerintah Kota Jambi akan terus berupaya untuk menertibkan PKM ini agar jalan yang saat ini dipakai untuk berjualan para PKM, dapat difungsikan kembali sebagai jalan umum ketika Pasar Tradisional Angso Duo telah selesai direvitalisasi. Suasana Pasar Tradisional 16 Ilir pun tidak kalah semrawutnya dengan PKM yang berjualan di depan pasar yang banyak memakan jalan, akhirnya kemacetanpun sering terjadi. Satpol PP sering menertibkan mereka, tetapi ketika telah ditertibkan mereka kembali berjualan sebagaimana biasa. Sedangkan di Pasar Tradisional Cipulir suasana PKM berada di dalam pasar tidak berada di jalan utama, maka tidak heran apabila didapati PKM berjualan di lorong-lorong pasar, sedangkan jalan utama steril dari para PKM.

Pembinaan harus terus dilakukan terhadap para PKM dan pedagang pasar, karena berdasarkan penelitian saingan utama para pedagang tradisional adalah PKM. Agar tidak terjadi kesemrautan, dan menghindari persaingan antara pasar tradisional dengan PKM dan terjadi ketertiban. Hendaknya Pemerintah Kota melakukan zonasi bagi PKM agar mereka diberi lahan untuk berniaga di tempat lain. Jadi ada solusi dari Pemerintah Kota untuk PKM tidak hanya merazia mereka dengan mengerahkan Satpol PP, mereka pun punya hak yang sama untuk berniaga. Pemerintah Kota khususnya SKPD yang bertugas memiliki wewenang khusus menangani pembinaan pedagang pasar tradisional dan PKM yaitu Dinas Perindustrian dan Perdagangan, Koperasi dan Usaha Mikro Kecil dan Menengah (UMKM) dan pasar. Dengan demikian akan terjadi perpindahan konsumen pasar tradisional beralih ke pasar modern yang berakibat berkurangnya pendapatan pedagang tradisional. Apabila sudah begini akan susah untuk pasar tradisional bersaing dalam Masyarakat Ekonomi Asean (MEA) apalagi era global.

Melihat hasil observasi, kuesioner, dan interview terhadap para pedagang Pasar Tradisional Angso Duo Kota Jambi, 16 Ilir, dan Cipulir Jakarta Selatan, juga pemerintah Kota Jambi, Kota Palembang dan Kota Jakarta Selatan, serta 
para pembeli di pasar tradisional tiap daerah didapati bahwasannya revitalisasi pasar tradisional dan pembangunan Sumber Daya Manusia adalah langkah paling baik untuk menghadapai Masyarakat Ekonomi Asean (MEA) 2020. Salah satu program Presiden Republik Indonesia Ir. H. Joko Widodo adalah merevitalisasi 5000 pasar tradisional untuk periode 20142019. Langkah ini sangat efektif dalam menghadapi Masyarakat Ekonomi Asean (MEA) 2020 yang diperkirakan akan luar biasa, karena dalam Asean Free Tread Area (AFTA) kenyataannya Indonesia terbanjiri oleh produkproduk luar negeri khususnya produk China. Oleh karena itu pemerintah memiliki peranan sangat urgen dalam menyambut Masyarakat Ekonomi Asean yang memiliki dampak besar khususnya terhadap pasar tradisional yang merupakan tempat berkumpulnya pelaku usaha kecil menengah (UMKM) sebagai soko guru terhadap perekonomian nasional.

Tugas pemerintah tidaklah ringan untuk membangun Sumber Daya Manusia dan juga infrastruktur baik fisik maupun mental. Pembangunan infrastruktur khususnya dalam merevitalisasi pasar tradisional dan pemenuhan keperluan asas masyarakat (jalan, energi listrik dan air) adalah yang utama sebagai pendukung utama perekonomian dalam membangun Sumber Daya Manusia (SDM) dan peningkatan produk-produk dalam negeri. Dengan adanya pembangunan infrastruktur akan dapat meningkatkan kemampuan dalam mengolah potensi daerah khususnya pasar tradisional sebagai basis berkumpulnya mikro kecil dalam memasarkan produk-produk unggulan yang dihasilkan oleh alam baik berupa hasil pertanian, perkebuhan maupun home industry berupa produk yang berbasis Sumber Daya Manusia lokal yang prospektif, kreatif, inovatis serta berdaya saing baik lokal maupun internasional.

Peran Pemerintah sangat besar dalam membangun mindset dengan merevitalisasi pasar tradisional dan pembangunan kualitas Manusia merupakan program strategi dalam menghadapi sekaligus mengantisipasi Masyarakat Ekonom Asean, karena sasaran revitalisasi dan pembangunan ini 
adalah pemberdayaan para usahawan mikro yang tumbuh di daerah pasar dan belum memiliki fasilitas memadai, layak, sehat, bersih dan nyaman dalam bertransaksi. Revitalisasi pasar tradisional lebih menekankan kepada pembangunan fisik. Akibatnya banyak pasar tradisional yang telah direnovasi, selama beberapa tahun kembali semrawut, kumuh dan kotor seperti tidak pernah dilakukan renovasi atau revitalisasi. Para petugas pasar beralasan kurang dan terbatasnya anggaran daerah. Semua itu terjadi karena pembangunan pasar masih menyentuh bangunan fisik belum menyentuh kepada ruh, berupa manajerial yang baik ditambah aktivitas pemeliharan bangunan fisik pasar.

Setelah melakukan interview terhadap para pedagang dan Pemerintah Kota Dinas Perdagangan dan Industri bahwa strategi zonasi di Pasar Angso Dou, Pasar Tradisional 16 Ilir dan Pasar Tradisional Cipulir menjadi bagian pengelolaan pasar dan Pedagang Kaki Lima, Pemerintah Kota telah melakukan pemberdayaan kepada pedagang dan pengelola pasar dengan memberikan bimbingan, pelatihan dan penyuluhan, untuk selalu menjaga kebersihan, ketertiban pasar, penataan dagangan, cara berdagang yang baik, cara melayani costumer ketika berbelanja agar mereka datang kembali berbelanja dan tidak lepas program pemerintah memberikan penyuluhan terhadap persaingan global yang tengah terjadi.

Revitalisasi pasar yang dilakukan tidak hanya dilakukan oleh Pemerintah Daerah tetapi ada peran swasta yang ikut berkecimpung. Seperti pembangunan pasar tradisional Angso Duo yang pembangunannya melibatkan pihak swasta. Pihak swasta bertindak sebagai pengembang yang bermitra dengan Pemerintah Kota. Pihak pengembang dapat menjual kios-

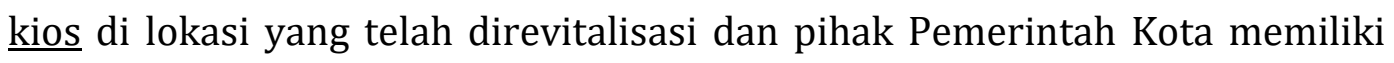
peran sebagai pengelola pasar setelah direvitalisasi. Hasil observasi terhadap beberapa pedagang pasar, mereka mengeluhkan dengan mahalnya harga kios di pasar yang baru direvitalisasi, dan Pasar Tradisional Angso Duo merupakan pasar tradisional terbesar di Asia Tenggara. Begitupun Pasar 
Tradisional 16 Ilir dan Pasar Cipulir yang sangat ramai dan padat. Pembangunan pasar yang besar dan megah dilakukan atas kolaborasi antara Pemerintah Kota dengan swasta dimaksudkan agar pasar tersebut dapat terus berkembang, hal ini mengingat banyak pasar-pasar modern yang juga berdekatan dengan pasar tradisional. Seperti di Pasar Angso Duo berdekatan dengan Ramayana dan Matahari disekitarnya, di Pasar Cipulir berdekatan dengan ITC begitupun dengan Pasar Tradisional 16 Ilir berdekatan dengan pasar ritel modern.

Catatan penulis mendapatkan bahwa Pasar Tradisional Angso Duo lama pun akan segera direvitalisasi mengingat pasar ini berada di tempat strategis, memiliki nilai sejarah tinggi, berada di jalur lintas air Sungai Batanghari. Begitupun Pasar Tradisional Cipulir yang sedang dilakukan renovasi dalam rangka mengatasi banjil diakibatkan luapan air Sungai Pasanggrahan. Sedangkan Pasar Tradisional 16 Ilir sedang melakukan penertiban terhadap membludaknya pedagang kaki lima (PKL) yang selalu memakan badan jalan sehingga kenyamanan pengunjung banyak terganggu.

\section{E. Simpulan}

Strategi adaptasi pasar tradisional dalam menghadapi ancaman ekonomi, Masyarakat Ekonomi Asean adalah melestarikan pasar tradisional atau yang lebih dikenal pasar rakyat merupakan warisan budaya bangsa yang dilestarikan yang dijadikan basis soko guru perekonomian bangsa, dan menjadikan pasar tradisional lebih tahan terhadap krisis, dengan keharusan peningkatan tata kelola pasar, transparansi dalam penggunaan dana retribusi pasar dan mengarahkan pasar tradisional dengan tujuan bersaing dengan pasar modern. Langkah strategi pemerintah dalam mengadaptasi pasar tradisional adalah membuat stakeholder pemangku kebijakan yang pro rakyat Indonesia dengan cara merevitalisasi pasar tradisional yaitu fisik yang dibarengi dengan pembangunan sumber daya manusia non fisik, merevitalisasi pasar diikuti dengan sistem manajemen yang baik. Adapun 
yang menajadi Peran Pemerintah Kota dalam mengembangkan potensi daerah khususnya pasar tradisional Angso Duo, Pasar Tradisional 16 Ilir dan Pasar Tradisional Cipulir adalah diantaranya pemerintah merevitalisasi Pasar Tradisional Angso Duo, Pasar Tradisional 16 Ilir dan Pasar Tradisional Cipulir dan yang paling penting pemerintah hendaklah menaikan taraf pasar tradisional sesuai standar International Organization for Standardization (ISO).

\section{F. Daftar Pustaka}

Abdullah Sahroni (2015), "Implementasi Strategi Pemasaran Rasulullah Dalam Konteks Kontemporer (Analisis di Swalayan Pamella Yogyakarta dan La Tansa Gontor Ponorogo)", Jurnal Millah Vol. XV, No. 1, Agustus 2015.

Al-Hadits riwayat Abū Dawūd, at-Tirmidzī, Ibnu Mājah, dan asy-Syaukāni.

Al-Imām ibn Kathīr Ad-Damishqi (700-774 H). Translated by Muhammād Mustaphā Geme'ah, Al-Azhar (t.t), Stories of the Prophets. Published by Darussalam, Riyadh, Saudi Arabia.

Al-Qur"ān Nūr Karīm, Departemen Agama Republik Indonesia

Ariawan Gunadi meneliti tentang, "ASEAN Economic Community Impact For Indonesia", Jurnal. Jurnal Opinio Juris, Vol. 19 Januari - April 2016, Universitas Gadjah Mada, Bulaksumur Yogyakarta 55281.

Association of Southeast Asian Nations (2008), "Asean Economic Community Blueprint”, Book Asean Economic Community Blueprint, Jakarta: ASEAN Secretariat.

Atep Abdul Rofiq (2014), "Menakar Pengaruh Masyarakat Ekonomi ASEAN 2015 Terhadap Pembangunan Indonesia", Jurnal. Salam; Filsafat dan Budaya Hukum, Fakultas Syari'ah dan Hukum UIN Jakarta, Jl. Ir. H. Juanda No. 95 Ciputat, Jakarta. 
Bank Indonesia (2012), "Masyarakat Ekonomi Asean (MEA), Berbenah Atau Jadi Penonton", Jurnal. Jurnal Gerai Info, Edisi 28, Juli 2012, Newsletter Bank Indonesia, Humas Bank Indonesia, Jl. M. H. Thamrin 2 - Jakarta.

Budianto Tedjasuksmana (2014), "Potret UMKM Indonesia Menghadapi Masyarakat Ekonomi ASEAN 2015", Jurnal. The 7th NCFB and Doctoral Colloquium 2014 Towards a New Indonesia Business Architecture Sub Tema: "Business And Economic Transformation Towards AEC 2015" Pascasarjana, Universitas Katolik Widya Mandala Surabaya, UKWMS ISSN: $1978-6522$.

Claudia Vanesha Pitoy, Altje Tumbel dan Maria Tielung (2013), “Analisis

Strategi Bersaing Dalam Persaingan Usaha Bisnis Document Solution (Studi Kasus Pada PT. Astragraphia, Tbk Manado)", Jurnal. Jurnal Berkala Ilmiah Efisiensi Volume 16 No. 03 Tahun 2016, Jurusan Manajemen, Fakultas Ekonomi dan Bisnis, Universitas Sam Ratulangi, Manado 95115, Indonesia.

Dayat NS Wiranta (2015), “Penguatan Peran Pemerintah Daerah dalam Mendorong

Pertumbuhan Ekonomi Lokal: Peluang dan Tantangan Masyarakat Ekonomi Asean (MEA) 2015", Jurnal. Lingkar Widyaiswara, Edisi 2 No. 3, Jul Sep 2015, Widyaiswara pada Pusat dan Pendidikan dan Pelatihan Aparatur. I (PKP2A.I) LAN, Jl. Kiarapayung Km. 4,7 JatinangorSumedang

Dewi Azimah, Rina Martini, Dzunuwanus Ghulam Manar (2013), “Kontribusi Pasar Tradisional Dan Pasar Modern Terhadap Pendapatan Asli Daerah Kota Semarang Tahun 2011 (Studi Kasus Di Wilayah Kecamatan Banyumanik)", Jurnal. Jurnal Ilmu Pemerintahan, Volume 2, Nomor 2. Jurusan Ilmu Pemerintahan, Fakultas Ilmu Sosial dan Ilmu Politik, Universitas Diponegoro Jl. Prof. Soedharto, Tembalang, Semarang. 
Dhika Putri Awwallin (t.t.), "Peluang, Tantangan dan Propek Perbankan Syari'ah Indonesia Dalam Menghadapi Persaingan Masyarakat Ekonomi ASEAN (MEA) 2015”, eJurnal. eJurnal, Universitas Negeri Surabaya.

Diar Wulandari, Evi Dwy Tasari, Ghora Putra Sena, Imam Rofi'I (t.t.), “eCommerce Untuk Meningkatkan Daya Saing Usaha Mikro Kecil Menengah Dalam Menghadapi Masyarakat Ekonomi ASEAN", Jurnal. International Research and Development for Human Beings, Universitas Negeri Malang.

Endi Sarwoko (2008), “Dampak Keberadaan Pasar Modern Terhadap Kinerja Pedagang Pasar Tradisional di Wilayah Kabupaten Malang", Jurnal. Jurnal Ekonomi ODERNISASI Volume 4, Nomor 2, Juni 2008, Fakultas Ekonomi - Universitas Kanjuruhan Malang.

Eny Sulistyanigrum dan Elphiwin Adela (2001), "Implikasi Krisis Ekonomi Terhadap Desa Idt Dan Desa Bukan Idt: Studi Komparatif Desa Purwoharjo Dan Desa Gerbosari, Kecamatan Samigaluh, Kabupaten Kulonprogo, Diy", Jurnal. Jurnal Ekonomi dan Bisnis Indonesia, Vol. 16, No. 1, 2001, 30 - 40, Universitas Gadjah Mada.

Erliz Nindi Pratiwi dan Rifa Atun Mahmudah (2013), "Peningkatan Daya Saing Tenaga Kerja Indonesia Melalui Korelasi Input Penunjang Tenaga Kerja Dalam Menghadapi MEA 2015", Jurnal.Economics Development Analysis Journal, Jurusan Ekonomi Pembangunan, Fakultas Ekonomi, Universitas Negeri Semarang, Indonesia, Gedung C6 lantai 1, Kampus Sekaran Gunungpati, Semarang 50229.

Evita Sari (t.t), "Analisis Pengelolaan Retribusi Parkir Pada Perusahaan Daerah Pasar Palembang Jaya Dalam Meningkatkan Pendapatan Asli Daerah (PAD) Kota Palembang", Jurnal. Jurnal Akuntansi

Fitri Nuraini, Rieska Maharani dan Andrianto (2016), "Strategi Peningkatan Daya Saing UMKM Dan Koperasi Dalam Menghadapi AEC (ASEAN Economic Community): Suatu Telaah Kepustakaan", Prosiding. Prosiding Seminar Nasional Ekonomi dan Bisnis \& Call For Paper FEB UMSIDA 
STRATEGI ADAPTASI PASAR TRADISIONAL DALAM MENGHADAPI ANCAMAN EKONOMI MASYARAKAT EKONOMI ASEAN DI INDONESIA

2016, Jurusan Akuntansi Universitas Muhammadiyah Surabaya, Jl. Sutorejo 59 Surabaya.

Hansen Rusliani (2014), “Muamalah Negara Terhadap Sumber Daya Alam

Dan Sumber Daya Manusia Menuju Negara Maju: Studi Kritis Terhadap

Kebijakan Pemerintah", Jurnal. Jurnal Syari'ah, Vol. II, No. II, Oktober 2014, Fakultas Ilmu Agama Islam, Universitas Islam Indragiri Hilir.

Hry (2017), “Angso Duo, Pasar Tradisional Terbesar di Indonesia”, Artikel.

Seru Jambi, Barometer Masa Depan Jambi.

Humphrey Wangke (2014), "Peluang Indonesia Dalam Masyarakat Ekonomi Asean 2015", Jurnal. Jurnal Hubungan Internasional, Info Singkat, Vol. VI, No. 10/II/P3DI/Mei/2014, Bidang Hubungan Internasional, Pusat Pengkajian, Pengolahan Data, dan Informasi (P3DI) Setjen DPR RI.

Ikatan Pedagang Pasar Indonesia (2014), “IKAPPI: UU Perdagangan Lemahkan Pasar Tradisional", Artikel. Harian Ekonomi Neraca.

Kamus Besar Bahasa Indonesia (KBBI), Kamus Versi Online Dalam Jaringan.

Kementerian BAPPENAS (2012), Penurunan Peringkat Daya Saing Indonesia

Tahun 2012. Kementerian Perencanaan Pembangunan

Nasional/Badan Perencanaan Pembangunan Nasional (BAPPENAS) Jalan Taman Suropati No.2, Jakarta 10310.

M. Ari Sabilah Rahman (2015), “Daya Saing Tenaga Kerja Indonesia Dalam Menghadapi Masyarakat Ekonomi Asean (MEA)", ejournal. eJournal Ilmu Hubungan Internasional, Fakultas Ilmu Sosial dan Ilmu Politik, Universitas Mulawarman.

Mahmud Syarif, Ayu Azizah, Ade Priyatna (2015), “Analisis Perkembangan dan Peran Industri Kreatif Untuk Menghadapi Tantangan MEA 2015", Seminar. Seminar Nasional Inovasi dan Tren (SNIT) 2015, Prosiding, Universitas BSI Bandung.

Mariza Shabastian dan Hatane Samuel (2013), Pengaruh Strategi Harga dan Strategi Produk Terhadap Brand Loyalty di Tator Café Surabaya Town Square", Jurnal. Jurnal Manajemen Pemasaran Vol. 1, No. 1, (2013) 1-9, 
STRATEGI ADAPTASI PASAR TRADISIONAL DALAM MENGHADAPI ANCAMAN

EKONOMI MASYARAKAT EKONOMI ASEAN DI INDONESIA

Manajemen Pemasaran, Universitas Kristen Petra. Jl. Siwalankerto 121131, Surabaya.

Masagus M. Ridhwan, Gunawan Wicaksono, Linda Nurliana, Pakasa Bary, Fenty Tri Suryani, Redianto Satyanugroho (2015), “Analisis Daya Saing dan Strategi Industri Nasional di Era Masyarakat Ekonomi ASEAN dan Perdagangan Bebas", Working Paper. BI, Jl MH Thamrin No 2, Jakarta 10350.

Maurice Bucaille (2005),What is Origin of Man? The Answers of Science and The Holy Scriptures. Diterjemahkan oleh Rahmani Astuti (1992), AsalUsul Manusia Menurut Bibel, al-Qur'an dan Sains. Mizan, Bandung.

Mia Angelina Setiawan (2015), "Peranan Investasi Sektor Riil Untuk Meningkatkan Perekonomian Di Sumatera Barat Dalam Menghadapi Masyarakat Ekonomi ASEAN", Prosiding.Book of Proceedings, Fakultas Ekonomi Universitas Negeri Padang Jln. Prof. Dr. Hamka, Kampus UNP Air Tawar Padang.

Michael G. Plummer (2006), "The ASEAN Economic Community and the European Experience", Working Paper. Working Paper Series on Regional Economic Integration No. 1, Office of Regional Economic Integration, ADB.

Normaz Wana Ismail and Collin Wong Koh King (2013), "The Effects of ASEAN Free Trade Agreement (AFTA) on Intra ASEAN Trade: 19862010", Journal. Pertanika J. Social Sciences \& Humanities 21 (S): 115 124 (2013), Universiti Putra Malaysia, 43400 Serdang, Selangor, Malaysia.

Nur Diyahfitriani (2015), "Strategi Hadapi MEA; Revitalisasi Pasar Tradisional", Artikel. Koran Muria, Koran Online Lokal-Berani Beda, Tak Asal Bicara, Kabupaten Kudus, Jawa Tengah, Selasa 26 Mei 2015.

Nurlidiawati (2014), "Sungai Sebagai Wadah Awal Munculnya Peradaban Umat Manusia", Jurnal. Jurnal Rihlah Vol. 1. No. 2. 2014, Fakultas Adab dan Humaniora UIN Alauddin Makassar. 
Pandasurya Wijaya (2012), "8 Waralaba asing antre masuk Indonesia", Artikel. Merdeka.com, Selasa 4 September 2012.

Pemerintah Kota Jambi (2002-2003), Profil Kabupaten/Kota Jambi, Pemerintah Kota Jambi.

Pemerintah Kota Jambi (2013-2018), “Aspek Geografi dan Demografi”, Bab II Gambaran Umum Kondisi Daerah. Rencana Pembangunan Jangka Menengah Daerah (RPJMD) (2013-2018).

Pertumbuhan Ekonomi Lokal: Peluang dan Tantangan Masyarakat Ekonomi ASEAN(MEA) 2015", Jurnal. Jurnal Lingkar Widyaiswara, Edisi 2 No. 3, Jul - Sep 2015, Widyaiswara Madya pada Pusat Kajian dan Pendidikan dan Pelatihan Aparatur, I (PKP2A.I).

Porter, M.E. (1980), Competitive Strategy. Free Press, New York, 1980. Dalam Dayat NS Wiranta (2015), "Penguatan Peran Pemerintah Daerah dalam Mendorong

Rahadi Wasi Bintoro (2010), “Aspek Hukum Zonasi Pasar Tradisional dan

Pasar Modern", Jurnal. Jurnal Dinamika Hukum, Vol. 10, No. 3, September 2010, Fakultas Hukum Universitas Jenderal Soedirman.

Reza Sasanto, Muhammad Yusuf (2010), "Identifikasi Karakteristik Pasar Tradisional Wilayah Jakarta Selatan (Studi Kasus: Pasar Cipulir, Pasar Kebayoran Lama, Pasar Bata Putih, Dan Pasar Santa)", Jurnal. Jurnal PLANESATM Vol. 1, No. 1, Mei 2010, Jurusan Teknik PlanologiUniversitas Esa Unggul, Jakarta.

Robby Darwis Nasution (t.t.), “Menyongsong Masyarakat Ekonomi ASEAN (MEA): Sebuah Peluang atau Ancaman? (Tinjauan Kritis Terhadap Inovasi Pemerintah Daerah Dalam Menghadapi Pasar Bebas)", Artikel. Universitas Muhammadiyah Ponorogo Jl. Budi Utomo No. 10 Ponorogo. Robert Green (2006), The 33 Strategies of War. Viking Published by the Peguin Group (USA) ～Inc., 375 Hudson Street, New York 10014, U.S.A.

Ryan Faza Prasetyo dan I Putu Artama Wiguna (2015), Menilai Kesadaran dan Kesiapan Kontraktor di Indonesia Menghadapi Masyarakat Ekonomi 
STRATEGI ADAPTASI PASAR TRADISIONAL DALAM MENGHADAPI ANCAMAN EKONOMI MASYARAKAT EKONOMI ASEAN DI INDONESIA

ASEAN",Prosiding. Prosiding Seminar Nasional Manajemen

Teknologi XXII Program Studi MMT-ITS, Surabaya 24 Januari 2015Fakultas Teknik Sipil dan Perencanaan, Institut Teknologi Sepuluh Nopember.

Septiana Dwiputri Maharani (2016), “Manusia Sebagai Homo Economicus:

Refleksi Atas Kasus-Kasus Kejahatan di Indonesia”, Jurnal. Jurnal Filsafat, Vol. 26, No. Februari 2016, Fakultas Filsafat Universitas Gadjah Mada.

Sugihardjo, dkk (2012), "Strategi Bertahan Dan Strategi Adaptasi Petani

Samin Terhadap Dunia Luar (Petani Samin Di Kaki Pegunungan Kendeng

Di Sukolilo Kabupaten Pati)", Jurnal. Fakultas Pertanian UNS, Program

Studi Agribisnis, SEPA : Vol. 8 No. 2 Pebruari 2012: 145-153, ISSN : 1829-9946.

Supriyanto (2006), "Pemberdayaan Usaha Mikro, Kecil, dan Menengah (UMKM) Sebagai Salah Satu Upaya Penanggulangan Kemiskinan", Jurnal. Jurnal Ekonomi \& Pendidikan, Volume 3 Nomor 1, April 2006, Fisipol UNY.

Sutrisno, Teguh Sumarsono (2015), "Pengelolaan Sampah Organik Pasar Angso Duo Jambi Menjadi Biogas Bagi Masyarakat Sekitar", Jurnal. Jurnal Pengabdian pada Masyarakat, Volume 30, Nomor 3 Juli - September 2015, Fakultas Sains danTeknologi Universitas Jambi.

Thorik Gunara dan Utus Hardiono Sudibyo (2007), Marketing Nabi Muhammad

Shalallahu'alaihi wa Sallam, Strategi Andal dan Jitu Praktik Bisnis Nabi Muhammad Muhammad Shalallahu'alaihi wa Sallam. Madani Prima, Imprint dari Salamadani Pustaka Semesta, PT Karya Kita, Bandung Indonesia.

Tiesnawati Wahyuningsih (2015), "Peluang Tenaga Kerja Indonesia Dalam Menghadapi MEA 2015”, Seminar. Prosiding Seminar Nasional, Fakultas Ilmu Sosial dan Ilmu Politik, Universitas Terbuka, UTCC, 26 Agustus 2015. 
STRATEGI ADAPTASI PASAR TRADISIONAL DALAM MENGHADAPI ANCAMAN EKONOMI MASYARAKAT EKONOMI ASEAN DI INDONESIA

Toti Indrawati dan Indri Yovita (2014), “Analisis Sumber Modal Pedagang

Pasar Tradisional di Kota Pekanbaru", Jurnal. Jurnal Ekonomi, Volume 22, Nomor 1 Maret 2014, Jurusan Ilmu Ekonomi Prodi Ekonomi Pembangunan Fakultas Ekonomi Unri Kampus Bina Widya Km 12,5 Simpang Baru, Pekanbaru.

Tri Widodo dan Bertha Kusuma Wardani (2012), "Strategi Equilibrium Pasar

Tradisional Mensiasati Kepungan Pasar Modern", Jurnal. Jurnal Ilmiah Among Makarti Vol.5 No.10, Desember 2012, Sekolah Tinggi Ilmu Ekonomi "AMA" Salatiga.

Victor M. Manek Kiik (2006), Kajian Faktor-Faktor Yang Mempengaruhi Tidak Optimalnya Fungsi Pasar Tradisional Lolowa Dan Pasar Tradisional Fatubenao Kecamatan Kota Atambua - Kabupaten Belu, Tesis. Program Pasca Sarjana Magister Pembangunan Wilayah Dan Kota Undip Semarang.

Wasilah, Aisyah Rahman Dan Muhammad Misbahuddin (2017), "Pasar Tradisional Dengan Penataan Modern di Kota Makassar", Jurnal. Jurnal Nature, National Academic Journal of Architecture, Volume 4, Nomor 1, 2017, p-ISSN: 2302-6073, e-ISSN: 2579-4809.

Willy Arafah (2015), "Implementasi Masyarakat Ekonomi ASEAN Terhadap

Pemerataan Kesempatan Kerja", Jurnal. Jurnal Ekobis (Ekonomi, Keuangan dan Bisnis Islam), Volume: 1, Nomor 01, April - September 2015, Universitas Trisakti.

Wiryanto Dewobroto (2014), "Peran Kompetisi Dalam Pendidikan Untuk Meluluskan Insinyur Yang Tangguh", Conference Paper. Workshop Peningkatan Daya Saing Dalam Kompetisi Internasional Teknik Sipil, Jurusan Teknik Sipil, Fakultas Teknik, Universitas Brawijaya, Sabtu, 10 Mei 2014, Ruang Sidang Jurusan Sipil Gedung A Lantai 2, Malang.

Zumrottus Sa'adah (2015), "Jati Diri Bangsa dan Potensi Sumber Daya Konstruktif", Prosiding Seminar Nasional. Program Pasca Sarjana Universitas Negeri Surabaya (UNESA) 


\section{STRATEGI ADAPTASI PASAR TRADISIONAL DALAM MENGHADAPI ANCAMAN EKONOMI MASYARAKAT EKONOMI ASEAN DI INDONESIA}

\section{Catatan}

${ }^{1}$ Humphrey Wangke (2014),"Peluang Indonesia Dalam Masyarakat Ekonomi Asean 2012”,
Jurnal. Info Singkat Hubungan Internasional, Pusat Pengkajian, Pengolahan Data dan Informasi
(P3DI), Sek-Jenderal DPR RI, h. 6.
${ }^{2}$ Association of Southeast Asian Nations (2008), “Asean Economic Community Blueprint", Book.
Asean Economic Community Blueprint, Jakarta: ASEAN Secretariat, p. 5.
${ }^{3}$ Association of Southeast Asian Nations (2008), Ibid., p. 5, dan Dokumen Departemen
Perdagangan Republik Indonesia, Menuju ASEAN Economic Community 2015.
${ }^{4}$ Zumrottus Sa'adah (2015), "Jati Diri Bangsa dan Potensi Sumber Daya Konstruktif”, Prosiding
Seminar Nasional. Program Pasca Sarjana Universitas Negeri Surabaya (UNESA), h. 738.
${ }^{5}$ Zumrottus Sa'adah (2015), Ibid., h. 738. ${ }^{6}$ Kementerian Perdagangan Republik Indonesia (2015), Warta Ekspor. "Peluang dan Tantangan Indonesia Pasar Bebas Asean, Masyarakat Ekonomi Asean (MEA)". Ditjen PEN/WRT/04/I/2015 edisi Januari, hal. 2.

${ }^{7}$ M. Ari Sabilah Rahman (2015), "Daya Saing Tenaga Kerja Indonesia Dalam Menghadapi Masyarakat Ekonomi Asean (MEA)", ejournal. eJournal Ilmu Hubungan Internasional, Fakultas Ilmu Sosial dan Ilmu Politik, Universitas Mulawarman, h. 118.

${ }^{8}$ Rahadi Wasi Bintoro (2010), “Aspek Hukum Zonasi Pasar Tradisional dan Pasar Modern", Jurnal. Jurnal Dinamika Hukum, Vol. 10, No. 3, September 2010, Fakultas Hukum Universitas Jenderal Soedirman, h. 361.

${ }^{9}$ Rahadi Wasi Bintoro (2010), Ibid., h. 361.

${ }^{10}$ Rahadi Wasi Bintoro (2010), Ibid., h. 361.

${ }^{11}$ Rahadi Wasi Bintoro (2010), Ibid., h. 361.

${ }^{12}$ Tri Widodo dan Bertha Kusuma Wardani (2012), "Strategi Equilibrium Pasar Tradisional Mensiasati Kepungan Pasar Modern”, Jurnal.Jurnal IlmiahAmong Makarti Vol.5 No.10, Desember 2012, Sekolah Tinggi Ilmu Ekonomi "AMA" Salatiga, h. 8.

${ }^{13}$ Tri Widodo dan Bertha Kusuma Wardani (2012), Ibid., h. 2.

${ }^{14}$ Supriyanto (2006), "Pemberdayaan Usaha Mikro, Kecil, dan Menengah (UMKM) Sebagai Salah Satu Upaya Penanggulangan Kemiskinan”, Jurnal. Jurnal Ekonomi \& Pendidikan, Volume 3 Nomor 1, April 2006, Fakultas Ilmu Sosial dan Ekonomi, Universitas Negeri Yogyakarta, h. 1.

${ }^{15}$ Pemerintah Kab. Pati (2014), "Kelebihan Dan Kelemahan Pasar Tradisional, Pasar Tradisional dan Pasar Modern" Situs Resmi. Pemerintah Kabupaten Pati, Pati Bumi Mina Tani. Senin 10 Maret 2014.

${ }^{16}$ Endi Sarwoko (2008), "Dampak Keberadaan Pasar Modern Terhadap Kinerja Pedagang Pasar Tradisional di Wilayah Kabupaten Malang", Jurnal. Jurnal Ekonomi MODERNISASI, Volume 4, Nomor 2, Juni 2008, Fakultas Ekonomi - Universitas Kanjuruhan Malang, h. 102.

${ }^{17}$ Bank Indonesia (2012), "Masyarakat Ekonomi Asean (MEA), Berbenah Atau Jadi Penonton", Jurnal. Jurnal Gerai Info, Edisi 28, Juli 2012, Newsletter Bank Indonesia, Humas Bank Indonesia, Jl. M. H. Thamrin 2 - Jakarta, h. 1.

${ }^{18}$ Kementerian BAPPENAS (2012), Penurunan Peringkat Daya Saing Indonesia Tahun 2012. Kementerian Perencanaan Pembangunan Nasional/Badan Perencanaan Pembangunan Nasional (BAPPENAS) Jalan Taman Suropati No.2 Jakarta 10310, Telp. 02131936207 Fax 0213145374.

${ }^{19}$ Marsela (2016), "Hadapi MEA, Siapkan UKM, Tingkatkan Daya Saing”, Majalah. Marsela, Majalah Sekretariat Wakil Presiden, Volume 1/Tahun XI/2016, Medan Merdeka Selatan, Sekretariat Wakil Presiden J1. Kebon Sirih No. 14, Jakarta Pusat, h. 6.

${ }^{20}$ Ikatan Pedagang Pasar Indonesia (2014), "IKAPPI: UU Perdagangan Lemahkan Pasar Tradisional", Artikel. Harian Ekonomi Neraca.

${ }^{21}$ Ikatan Pedagang Pasar Indonesia (2014), Ibid., Harian Ekonomi Neraca.

${ }^{22}$ Endi Sarwoko (2008), op.cit, h. 98. 


\section{STRATEGI ADAPTASI PASAR TRADISIONAL DALAM MENGHADAPI ANCAMAN EKONOMI MASYARAKAT EKONOMI ASEAN DI INDONESIA}

\footnotetext{
${ }^{23}$ Nur Diyahfitriani (2015), "Strategi Hadapi MEA; Revitalisasi Pasar Tradisional”, Artikel. Koran Muria, Koran Online Lokal-Berani Beda, Tak Asal Bicara, Kabupaten Kudus, Jawa Tengah, Selasa 26 Mei 2015.

${ }^{24}$ Pandasurya Wijaya (2012), "8 Waralaba asing antre masuk Indonesia", Artikel. Merdeka.com, Selasa 4 September 2012.

25 "Dan Kami tidak mengutus rasul-rasul sebelummu (Muhammad), melainkan mereka sungguh memakan makanan dan berjalan di pasar-pasar. Dan Kami jadikan sebagian kamu cobaan bagi sebagian yang lain. Maukah kamu bersabar? dan Tuhanmu Maha Melihat. Sūrah al-Furqān (25) : 20.
}

"Hai orang -orang yang beriman, janganlah kamu saling memakan harta sesamamu dengan jalan yang batil, kecuali dengan jalan perniagaan yang berlaku dengan suka sama-suka di antara kamu. Dan janganlah kamu membunuh dirimu. Sesungguhnya Allah Maha Penyayang kepadamu’. Sūrah an-Nisā (4) : 29.

${ }^{26}$ Dalam hadits Rasulullah saw, telah dijelaskan mengenai mekanisme pasar. Manusia berkata: "Wahai Rasulullah saw, tentukanlah harga untuk kita! Beliau menjawab; Allah SWT itusesungguhnya adalah penentu harga, penahan, pencurah serta pemberi rizki. Aku mengharapkan dapat menemui Tuhanku di mana salah seorang dari kalian tidak menuntutkukarena kezhaliman dalam hal darah dan harta". (Hadits Riwayat; Abū Dawūd, atTirmidz̄i, Ibnu Mājah, dan asy-Syaukāni).

${ }^{27}$ Keputusan Presiden Republik Indonesia Nomor 37 Tahun 2014, ditetapkan di Jakarta, pada tanggal 1 September 2014 oleh Presiden Republik Indonesia Dr. H. Susilo Bambang Yudhoyono.

${ }^{28}$ Perpres Nomor 112 Tahun 2007 juga menjelaskan definisi pasar dan pasar tradisional.

${ }^{29}$ Dalam Peraturan Menteri Perdagangan No. 53/M-DAG/PER/12/2008 dijelaskan bahwa pasar tradisional adalah pasar yang dibangun dan dikelola oleh pemerintah, pemerintah daerah, swasta, badan usaha milik negara dan badan usaha milik daerah termasuk kerjasama dengan swasta dengan tempat usaha berupa toko, kios, los dan tenda yang dimiliki/dikelola oleh pedagang kecil, menengah, swadaya masyarakat atau koperasi dengan usaha skala kecil, modal kecil dan dengan proses jual beli barang dagangan melalui tawar-menawar.

${ }^{30}$ Porter, M.E. (1980), Competitive Strategy. Free Press, New York, 1980. Dalam Dayat NS Wiranta (2015), "Penguatan Peran Pemerintah Daerah dalam Mendorong Pertumbuhan Ekonomi Lokal: Peluang dan Tantangan Masyarakat Ekonomi ASEAN (MEA) 2015", Jurnal. Jurnal Lingkar Widyaiswara, Edisi 2 No. 3, Jul - Sep 2015, Widyaiswara Madya pada Pusat Kajian dan Pendidikan dan Pelatihan Aparatur. I (PKP2A.I), h. 37.

${ }^{31}$ Dayat NS Wiranta (2015), Ibid., h. 37.

${ }^{32}$ Dayat NS Wiranta (2015), Ibid., h. 37.

${ }^{33}$ Undang-Undang Republik Indonesia Nomor 23 Tahun 2014 Tentang Pemerintah Daerah.

${ }^{34}$ Three Idiots dalam menit 19:54.

${ }^{35}$ Wiryanto Dewobroto (2014), "Peran Kompetisi Dalam Pendidikan Untuk Meluluskan Insinyur Yang Tangguh", Conference Paper. Workshop Peningkatan Daya Saing Dalam Kompetisi Internasional Teknik Sipil, Jurusan Teknik Sipil, Fakultas Teknik, Universitas Brawijaya, Sabtu, 10 Mei 2014, Ruang Sidang Jurusan Sipil Gedung A Lantai 2, Malang, hal. 1.

${ }^{36}$ Star Wars/Perang Bintang adalah seri film epik, fiksi ilmiah, opera antariksa Amerika Serikat yang disutradarai oleh George Lucas. Semenjak dirilisnya serial ini, film ini telah menjadi sebuah fenomena budaya dan menghasilkan banyak produksi film, buku, permainan video, serial televisi, dan banyak produk lainnya yang dipasarkan.

${ }^{37}$ Teori alam semesta yang terus berkembang-meluas. QS: Az-Zariyat (51):47.

${ }^{38}$ MPR RI (2011), Amandemen UUD 1945 Plus Atlas Berwarna. Cetakan pertama, Penerbit Pustaka Yustisia, Slemen Yogyakarta, hal. 6.

${ }^{39}$ Arief Daryanto (2007), "Peran Pasar Tradisional dan Modern Dalam Pemasaran Unggas", Majalah. MajalahTrobos, Analisis Agribisnis, Oktober 2007, hal. 63.

${ }^{40}$ Yudha Manggala P Putra (2016), "Pasar Tradisional Tulang Punggung Perekonomian", Republika. Ekonomi Republika, Sabtu 17 September 2016.

${ }^{41}$ Ketahanan terhadap krisis moneter salah satunya disebabkan oleh tidak bergantungnya atau bebas dengan faktor-faktor ekternal seperti ketergantungan dengan dolar AS. Pasar tradisional 


\section{STRATEGI ADAPTASI PASAR TRADISIONAL DALAM MENGHADAPI ANCAMAN EKONOMI MASYARAKAT EKONOMI ASEAN DI INDONESIA}

jarang bersentuhan dengan dolar AS, pembeli dan penjual langsung menggunakan sistem cash and carry. Barang-barang banyak didatangkan langsung dari kebun atau pabrik lalu masuk langsung ke pasar tradisional. Hal tersebut sesuai dengan penelitian dilakukan di Desa Gerbosari dan Desa Purwoharjo, kedua desa tersebut tidak terkena dampak signifikan dari krisis moneter tahun 1997. Eny Sulistyanigrum dan Elphiwin Adela (2001), "Implikasi Krisis Ekonomi Terhadap Desa Idt Dan Desa Bukan Idt: Studi Komparatif Desa Purwoharjo Dan Desa Gerbosari, Kecamatan Samigaluh, Kabupaten Kulonprogo, Diy", Jurnal. Jurnal Ekonomi dan Bisnis Indonesia, Vol. 16, No. 1, 2001, 30 - 40, Universitas Gadjah Mada, hal. 38.

${ }^{42}$ Thorik Gunara dan Utus Hardiono Sudibyo (2007), Marketing Nabi Muhammad SAW, Strategi Andal dan Jitu Praktik Bisnis Nabi Muhammad SAW. MadaniA Prima, Imprint dari Salamadani Pustaka Semesta, PT Karya Kita, Bandung - Indonesia, hal. 12.

${ }^{43}$ Abdullah Sahroni (2015), "Implementasi Strategi Pemasaran Rasulullah Dalam Konteks Kontemporer (Analisis di Swalayan Pamella Yogyakarta dan La Tansa Gontor Ponorogo)", Jurnal. Jurnal Millah Vol. XV, No. 1, Agustus 2015, hal. 122.

${ }^{44}$ Abdullah Sahroni (2015), Ibid., hal. 123.

${ }^{45}$ Claudia Vanesha Pitoy, Altje Tumbel dan Maria Tielung (2013), “Analisis Strategi Bersaing Dalam Persaingan Usaha Bisnis Document Solution (Studi Kasus Pada PT. Astragraphia, Tbk Manado)", Jurnal. Jurnal Berkala Ilmiah Efisiensi Volume 16 No. 03 Tahun 2016, Jurusan Manajemen, Fakultas Ekonomi dan Bisnis, Universitas Sam Ratulangi, Manado 95115, Indonesia, hal. 311.

${ }^{46}$ Mariza Shabastian dan Hatane Samuel (2013), Pengaruh Strategi Harga dan Strategi Produk Terhadap Brand Loyalty di Tator Café Surabaya Town Square", Jurnal. Jurnal Manajemen Pemasaran Vol. 1, No. 1, (2013) 1-9, Manajemen Pemasaran, Universitas Kristen Petra. Jl. Siwalankerto 121-131, Surabaya, hal. 3.

${ }^{47}$ Victor M. Manek Kiik (2006), Kajian Faktor-Faktor Yang Mempengaruhi Tidak Optimalnya Fungsi Pasar Tradisional Lolowa Dan Pasar Tradisional Fatubenao Kecamatan Kota Atambua Kabupaten Belu, Tesis. Program Pasca Sarjana Magister Pembangunan Wilayah Dan Kota Universitas Diponegoro Semarang, hal. 58.

${ }^{48}$ Rahadi Wasi Bintoro (2010), "Aspek Hukum Zonasi Pasar Tradisional dan Pasar Modern", Jurnal. Jurnal Dinamika Hukum, Vol. 10, No. 3, September 2010, hal. 361.

${ }^{49}$ QS: al-Anbiyā' $(21): 30$.

${ }^{50}$ Nurlidiawati (2014), "Sungai Sebagai Wadah Awal Munculnya Peradaban Umat Manusia", Jurnal. Jurnal Rihlah Vol. 1. No. 2. 2014, Fakultas Adab dan Humaniora UIN Alauddin Makassar, hal. 93.

${ }^{51}$ Nurlidiawati (2014), Ibid., hal. 96-102.

${ }^{52}$ Secara referensi memang belum disebutkan ciri-ciri khas pasar tradisional; tetapi dapat kita dapati bahwasanya pasar tradisional memiliki perbedaan yang mencolok dengan pasar modern yaitu di pasar tradisional terdapat sisi-sisi perekat hubungan sosial-masyarakat, kekeluargaan seperti adanya daya tawar menawar dalam proses jual beli, gotong-royong, saling bekerja sama, pusat pertemuan, pusat pertukaran informasi, terdapatnya aktivitas kesenian rakyat. Reza Sasanto, Muhammad Yusuf (2010), "Identifikasi Karakteristik Pasar Tradisional Di Wilayah Jakarta Selatan (Studi Kasus: Pasar Cipulir, Pasar Kebayoran Lama, Pasar Bata Putih, Dan Pasar Santa)", Jurnal. Jurnal PLANESATM Vol. 1, No. 1, Mei 2010, Jurusan Teknik Planologi - Universitas Esa Unggul, Jakarta, hal. 5.

${ }^{53}$ Hansen Rusliani (2014), "Muamalah Negara Terhadap Sumber Daya Alam Dan Sumber Daya Manusia Menuju Negara Maju: Studi Kritis Terhadap Kebijakan Pemerintah", Jurnal. Jurnal Syari'ah, Vol. II, No. II, Oktober 2014, Fakultas Ilmu Agama Islam, Universitas Islam Indragiri Hilir, hal. 66.

${ }^{54}$ Dalam detik finance disebutkan, "Kemendag Berencana Bantu Revitalisasi Pasar Angso Duo", Berita Ekonomi Bisnis. Rabu, 16 Juli 2014.

${ }^{55}$ Peraturan Menteri Perdagangan Republik Indonesia Nomor 37/M-Dag/Per/5/2017 Tentang Pedoman Pembangunan Dan Pengelolaan Sarana Perdagangan. 